\title{
Persepsi Ekowisatawan Domestik Terhadap Prostitusi Di Bali
}

Gilland Giovanni a,1, I Nyoman Sukma Arida a,2

${ }^{1}$ professional.giovanni@gmail.com ,22sukma.arida@gmail.com

a Program Studi S1 Destinasi Pariwisata, Fakultas Pariwisata,Universitas Udayana, Jl. Dr. R. Goris, Denpasar, Bali 80232 Indonesia

\section{Abstract}

The purpose of this research was to determine the domestic ecotourist perception against prostitution in Bali. Thus, the result of this research can be used as a reference to see how far the practice of prostitution is needed in a tourist destination, especially in Bali, of course from the point of view of domestic ecotourist as one of the target tourism markets. Data collection procedures using documentation studies and questionnaire to 30 domestic ecotourist in Eka Karya Bali Botanic Garden. Data were analyzed using a likert scale, presented in tables and graphics, and describe by descriptive qualitative. The results of this research revealed that, if prostitution in Bali is categorized as a positive action is not agreed. Then, if prostitution in Bali is categorized as a negative action, was agreed.

Keywords: Domestic Ecotourist, Perception, Prostitution

\section{PENDAHULUAN}

Seperti dua sisi mata uang yang berbeda, dampak positif dan dampak negatif selalu menyertai suatu pembangunan industri yang pada hakikatnya ialah untuk menciptakan kesejahteraan bagi masyarakat. Demikian hal nya dengan pembangunan pariwisata di suatu daerah. Terbukanya lapangan pekerjaan merupakan dampak positif pariwisata jika dilihat dari aspek ekonomi, namun persaingan antar tenaga kerja (skills), menimbulkan dampak sosial budaya lebih lanjut (Winaya, 2006). Para tenaga kerja yang "kalah" dalam persaingan, memicu tindakan-tindakan anormatif, salah satunya adalah prostitusi.

Bukan suatu hal yang mengejutkan apa yang dikatakan Hall, dalam Pitana dan Gayatri, (2005) bahwa seks atau prostitusi merupakan bagian integral dari pariwisata. Hal tersebut dikarenakan praktek-praktek prostitusi timbul karena adanya keinginan nafsu biologis sederhana, ketika semua sumber kepuasan dari semua individu tidak mampu memenuhi kebutuhan, maka prostitusi dapat dipakai sebagai alternatif untuk memenuhinya (Martiningsih, 2007). Sehingga dapat dikatakan bahwa prostitusi akan tetap ada walaupun industri pariwisata tidak ada. Namun, dalam perkembangannya, seks tidak hanya menjadi sekedar kebutuhan manusia untuk berketurunan, lebih jauh, juga sebagai aktifitas rekreasi di dalam rumah (indoor recreation) yang mampu memberikan efek relaksasi pada pelakunya (Wijayasa, 2006).

Prostitusi adalah salah satu bisnis yang selalu menyertai perkembangan sebuah destinasi pariwisata (Pitana dan Gayatri, 2005). Diperkuat pernyataan dari Wijayasa (2006), bahwa Bali sebagai destinasi pariwisata utama di Indonesia, tidak akan dapat luput dari fenomena prostitusi. Bali yang menggunakan budaya sebagai trademark pariwisata, tentu tidak mau "terjebak" dengan fenomena seks dalam pariwisata, namun jika seks (prostitusi) di Bali diakui tidak ada maka terlalu munafik mengingat ada kantong-kantong pekerja seksual yang memanfaatkan liburan wisatawan Bali sebagai suatu pangsa pasar yang digarap.

Dari uraian di atas jelas, bahwa keberadaan prostitusi merupakan dampak pariwisata yang dapat "di kemas" sedemikian rupa. Lihat saja bagaimana Thailand menerima devisa sebesar US\$ 4.3 Milyar per tahun dari sektor wisata seks (dikutip dari harian Berita Satu, 16 September 2012). Sehingga yang dikatakan Winia (2012), menjadi tepat bahwa prostitusi dapat mengayakan dari segi sosial ekonomi namun di sisi lain memiskinkan segi sosial kultural.

Menjamurnya praktek prostitusi di Bali adalah salah satu dampak negatif pembangunan pariwisata yang dapat dikatakan berorientasi ke mass tourism. Maka dari itu hadir suatu konsep alternative tourism yang memiliki jalan keluar untuk "mengobati sakit" dari pariwisata massal (Archer and Cooper, dalam Ruki, 2010). Konsep baru inilah yang kemudian popular dengan sebutan ekowisata (Arida, 2009). Tulisan ini membahas mengenai bagaimana persepsi ekowisatawan domestik terhadap praktek prostitusi di Bali. Hasil penelitian ini, sedikit memberikan gambaran sejauh mana 
praktek prostitusi dibutuhkan dalam industri pariwisata, dari sudut pandang ekowisatawan.

\section{TINJAUAN PUSTAKA}

\subsection{Konsep Ekowisatawan Domestik}

Perlu ditekankan bahwa yang dimaksud dengan ekowisatawan domestik dalam penelitian ini adalah wisatawan domestik yang berkunjung ke Kebun Raya Eka Karya Bali. Disebut sebagai ekowisatawan karena, Kebun Raya Eka Karya Bali teridentifikasi sebagai ekowisata tipe pemerintah, ditinjau dari teori "pola serba tiga" oleh Arida (2014). Jadi secara tidak langsung, wisatawan domestik yang berkunjung ke Kebun Raya Eka Karya Bali dapat digolongkan sebagai ekowisatawan domestik, karena sudah mengkonsumsi produk ekowisata.

\section{$2.2 \quad$ Konsep Persepsi}

Menurut Gibson, dalam Kusherdyana (2013), mengemukakan bahwa persepsi adalah proses kognitif yang digunakan oleh individu untuk menafsirkan dan memahami dunia sekitarnya. Lain halnya dengan Maryati (2009) dikutip dalam Pauwah (2013) mengatakan persepsi adalah suatu proses pemberian arti atau proses kognitif dari seseorang terhadap lingkungannya, yang dipergunakan untuk menafsirkan dan memahami dunia sekitarnya. Dengan demikian setiap orang akan berbeda cara pandang dan penafsirannya terhadap suatu objek atau fenomena tertentu. Jadi dapat dikatakan bahwa persepsi ialah proses pengorganisasian dimana manusia mengalami dan mengenali lingkungannya setelah mendapatkan stimulus atau rangsangan yang diterima oleh indrawi.

\subsection{Konsep Prostitusi}

Menurut Bonger, prostitusi adalah gejala kemasyarakatan yang ditandai dengan wanita "menjual diri" melakukan perbuatanperbuatan seksual sebagai mata pencaharian (Purnomo, dalam Winaya, 2006). Tidak jauh berbeda dengan yang dikemukakan Amstel (Kartono, dalam Winaya, 2006) bahwa prostitusi adalah penyerahan diri dari wanita kepada banyak laki-laki dengan pembayaran.

\subsection{Konsep Persepsi terhadap Prostitusi}

Dalam penelitian ini, digunakan konsep dari Martiningsih (2007) tentang persepsi wanita terhadap prostitusi. Meskipun dalam konsep ini digunakan sudut pandang wanita untuk melihat persepsi terhadap prostitusi, namun konsep ini dianggap relevan dan memadai untuk mengkaji masalah dalam penelitian ini. Secara garis besar persepsi wanita terhadap perkembangan prostitusi diklasifikasikan menjadi dua, yaitu persepsi negatif dan positif. Responden yang dikategorikan memiliki persepsi negatif dapat diindikasikan dengan beberapa variabel seperti berikut: (1) prostitusi sebagai perbuatan amoral, (2) prostitusi perlu ditertibkan, (3) prostitusi merupakan perbuatan terlarang, (4) prostitusi perlu ditindak tegas, (5) lelaki hidung belang perlu dihukum berat, (6) pemilik sarana akomodasi prostitusi perlu ditindak tegas, (7) prostitusi telah mengganggu kenyamanan dan ketentraman lingkungan sekitarnya, dan (8) prostitusi telah berada di luar batas toleransi. Responden yang berada dalam kategori positif dapat diindikasikan dengan beberapa variabel seperti berikut: (1) prostitusi merupakan perbuatan yang wajar-wajar saja, (2) prostitusi tidak perlu dilarang, (3) prostitusi perlu dilokalisasi, (4) prostitusi tidak bisa dieliminasi, (5) prostitusi tidak mengganggu ketertiban umum, (6) prostitusi tidak mengurangi kenyamanan tempat tinggal, dan (7) prostitusi masih dalam batas toleransi.

Dari keseluruhan variabel persepsi wanita terhadap prostitusi, baik yang masuk ke dalam kategori positif maupun negatif, diambil sebagian variabel dengan sedikit modifikasi sesuai dengan masalah kajian dan kebutuhan dalam penelitian ini. Sehingga didapatkan variabel sebagai berikut yang akan digunakan dalam penelitian : Kategori Positif (1) Prostitusi merupakan perbuatan yang wajar, (2) Adanya prostitusi membuat citra suatu destinasi wisata semakin baik, (3) Prostitusi merupakan kebutuhan bagi wisatawan saat berada di destinasi wisata, (4) Prostitusi menambah lama tinggal wisatawan di destinasi wisata, (5) Adanya prostitusi, merupakan alasan wisatawan untuk melakukan perjalanan ke suatu destinasi wisata, (6) Prostitusi perlu dilokalisasi, (7) Prostitusi dapat menambah devisa negara, (8) Prostitusi membuka peluang bisnis baru bagi pengusaha, (9) Pada akhirnya prostitusi merupakan permasalahan yang tidak dapat dihilangkan, (10) Prostitusi online merupakan solusi terbaik. Kategori Negatif (1) Prostitusi mengganggu ketentraman wisatawan di sebuah destinasi wisata, (2) Prostitusi 
mengurangi kenyamanan wisatawan saat berwisata, (3) Prostitusi identik dengan penyakit menular (HIV/AIDS), sehingga membuat wisatawan enggan terlibat dalam kegiatan prostitusi, (4) Prostitusi menurunkan nilai moral masyarakat lokal.

\section{METODE PENELITIAN}

\subsection{Lokasi Penelitian}

Pertimbangan dipilihnya Kebun Raya

Eka Karya Bali sebagai lokasi penelitian (penyebaran kuesioner) merujuk pada teori "pola serba tiga" oleh Arida (2014). Dalam teori tersebut digambarkan tipe-tipe ekowisata di Bali dilihat dari aktor utama yang menggerakkan serta manajemen yang diterapkan. Ketiga tipe tersebut antara lain: (1) Tipe investor (swasta), (2) Tipe pemerintah, (3) Tipe masyarakat.

Dalam kaitannya Kebun Raya Eka Karya Bali terpilih mewakili ekowisata tipe pemerintah. Juga mempertimbangkan prinsipprinsip ekowisata, dimana Kebun Raya Eka Karya Bali, dinilai sudah hampir memenuhi kriteria prinsip-prinsip tersebut.

\subsection{Teknik Pengumpulan Data}

Penelitian ini menggunakan kuesioner sebagai salah satu teknik pengumpulan data. Adapun yang dimaksud kuesioner adalah merupakan pertanyaan-pertanyaan penelitian yang direka khusus untuk mengumpulkan data kajian (Mustari, 2012). Adapun teknik studi dokumentasi juga digunakan dalam penelitian ini, dikarenakan sejumlah besar data dan fakta tersimpan dalam bahan yang berbentuk dokumentasi. Sifat utama data ini tak terbatas pada ruang dan waktu sehingga memberi peluang kepada peneliti untuk mengetahui halhal yang pernah terjadi pada waktu silam. Berbagai bahan dokumenter, antara lain buku, dokumen pemerintah atau swasta, website, dan artikel (Gunawan, 2013).

\subsection{Teknik Penentuan Sampel}

Teknik yang digunakan dalam menentukan sampel dalam penelitian ini adalah quota sampling atau teknik pemilihan sampel berdasarkan jumlah yaitu pemilihan sampel dengan memilih sejumlah tertentu (kuota) unsur populasi menjadi anggota sampel (Silalahi, 2012). Dalam penelitian ini, ditentukan sebanyak 30 responden. Jumlah tersebut dianggap telah mewakili populasi. Dari jumlah sampel yang telah ditentukan kemudian dipilih siapa subjek yang ada dalam posisi terbaik berdasarkan penilaian atas karakteristik anggota sampel yang dengannya diperoleh data yang sesuai dengan maksud penelitian. Teknik ini kemudian disebut sebagai purposive sampling (Silalahi, 2012).

\subsection{Teknik Analisis Data}

Untuk menganalisis data yang sudah terkumpul dibuatkan kategori persepsi dengan menggunakan metode pengukuran sikap (skala likert) melalui penyebaran kuesioner kepada responden. Pada setiap pertanyaan yang diajukan terdapat lima pilihan alternatif jawaban yang memiliki bobot yang berbeda. Selengkapnya pada Tabel 1 berikut:

Tabel 1

Skala Sikap Ekowisatawan

\begin{tabular}{rlcc}
\hline \multirow{2}{*}{ No } & \multicolumn{3}{c}{ Skala Sikap Wisatawan } \\
\cline { 2 - 4 } & \multicolumn{1}{c}{ Sikap } & Skor & Kategori \\
$\mathbf{1}$ & Sangat setuju & 5 & $>4,2-5,00$ \\
$\mathbf{2}$ & Setuju & 4 & $>3,4-<4,20$ \\
$\mathbf{3}$ & Moderat & 3 & $>2,6-<3,40$ \\
$\mathbf{4}$ & Tidak setuju & 2 & $>1,8-<2,60$ \\
$\mathbf{5}$ & Sangat tidak setuju & 1 & $1,0-<1,80$
\end{tabular}

Sumber : Hasil Modifikasi Skala Likert (Slamet, dalam Winaya, 2006)

Kemudian hasil dari pengukuran skala sikap, dijabarkan menggunakan teknik deskriptif kualitatif, yaitu analisis dengan memaparkan dan menguraikan keteranganketerangan atau data-data yang dikumpulkan selama melakukan penelitian (Muriawan, 2011). Hasil dari analisis data, disajikan dalam bentuk tabel dan gambar untuk mempermudah dalam memahami dan kemudian dikualitatifkan lagi untuk memperoleh kesimpulan yang jelas (Suharsimi, dalam Muriawan, 2011).

\section{HASIL DAN PEMBAHASAN}

\subsection{Gambaran Umum}

Kebun Raya Eka Karya Bali yang sejatinya populer di pandangan masyarakat dengan nama Kebun Raya Bedugul, terletak di Desa Candikuning, Kecamatan Baturiti, Kabupaten Tabanan, Bali, dengan ketinggian 1.250 - $1.450 \mathrm{mdpl}$, suhu berkisar antara 18 $20^{\circ} \mathrm{C}$ dan kelembaban $70-90 \%$ dan luas area 157,5 ha. Selengkapnya dapat dilihat pada Gambar 1. 


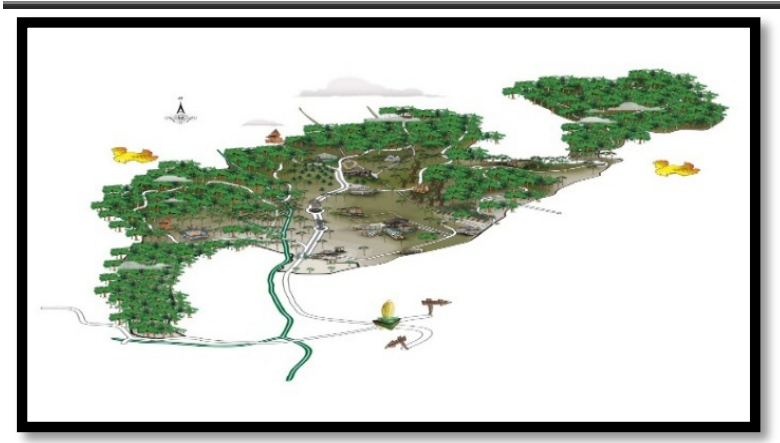

Gambar 1. Peta Kebun Raya Eka Karya Bali

\subsection{Persepsi Ekowisatawan Domestik terhadap Prostitusi di Bali \\ Untuk mengetahui persepsi} ekowisatawan domestik terhadap prostitusi di Bali, diajukan 14 buah pernyataan, yang terdiri dari 10 pernyataan kategori positif dan 4 pernyataan kategori negatif. Digunakan pengukuran skala sikap dengan tingkatan skor yang berbeda.

\section{a. Respon Kategori Positif}

Adapun persepsi ekowisatawan domestik jika prostitusi dikategorikan sebagai perbuatan yang positif dapat dilihat pada Tabel 2:

\begin{tabular}{|c|c|c|c|c|c|c|c|c|}
\hline \multirow{3}{*}{$\mathbf{P}$} & \multicolumn{8}{|c|}{$\begin{array}{c}\text { Tabel 2 } \\
\text { Respon Kategori Positif }\end{array}$} \\
\hline & \multicolumn{5}{|c|}{ SKOR KATEGORI RESPON } & \multirow{2}{*}{ TS } & \multirow{2}{*}{$\mathbf{R}$} & \multirow{2}{*}{$\mathbf{K}$} \\
\hline & SS (5) & $S(4)$ & $\mathrm{M}(3)$ & TS (2) & STS (1) & & & \\
\hline 1 & & 8 & 2 & 10 & 10 & 68 & 2.27 & TS \\
\hline 2 & & & 4 & 10 & 16 & 48 & 1.60 & STS \\
\hline 3 & & 2 & & 12 & 16 & 48 & 1.60 & STS \\
\hline 4 & 2 & & 2 & 12 & 14 & 54 & 1.80 & TS \\
\hline 5 & & 2 & & 12 & 16 & 48 & 1.60 & STS \\
\hline 6 & 10 & 12 & 4 & 4 & 0 & 118 & 3.93 & $\mathrm{~S}$ \\
\hline 7 & 2 & 2 & 18 & 8 & & 88 & 2.93 & M \\
\hline 8 & 2 & 6 & 12 & 6 & 4 & 86 & 2.87 & M \\
\hline 9 & 6 & 16 & 4 & 4 & & 114 & 3.80 & $\mathrm{~S}$ \\
\hline 10 & 2 & 2 & 6 & 12 & 8 & 68 & 2.27 & TS \\
\hline \multicolumn{6}{|c|}{ JUMLAH } & 740 & 24.67 & TS \\
\hline
\end{tabular}

Sumber: Analisis Data Primer, 2014

Berdasarkan hasil perhitungan skala likert pada Tabel 2 maka respon ekowisatawan domestik terhadap masing-masing pernyataan mengenai prostitusi di Bali adalah sebagai berikut:

1. Prostitusi merupakan perbuatan yang wajar (68/2.27/TS).

2. Adanya prostitusi membuat citra suatu destinasi wisata semakin baik (48/1.60/STS).

3. Prostitusi merupakan kebutuhan bagi wisatawan saat berada di destinasi wisata (88/1.60/STS).

4. Prostitusi menambah lama tinggal wisatawan di destinasi wisata (54/1.80/STS).
5. Prostitusi merupakan alasan wisatawan untuk melakukan perjalanan ke suatu destinasi wisata (48/1.60/STS).

6. Prostitusi perlu dilokalisasi (118/3.93/S)

7. Prostitusi dapat menambah devisa Negara (88/2.93/M).

8. Prostitusi membuka peluang bisnis baru bagi pengusaha $(86 / 2.87 / \mathrm{M})$

9. Pada akhirnya prostitusi merupakan permasalahan yang tidak dapat dihilangkan $(114 / 3.80 / \mathrm{S})$

10. Prostitusi online merupakan solusi yang terbaik (68/2.27/M).

Dari 10 pernyataan kategori positif diperoleh skor rata-rata sebesar 2.47. Jadi persepsi ekowisatawan domestik menunjukan sikap tidak setuju jika prostitusi di Bali dikategorikan sebagai perbuatan yang positif.

\section{b. Respon Kategori Negatif}

Adapun persepsi ekowisatawan domestik jika prostitusi dikategorikan sebagai perbuatan yang negatif dapat dilihat pada Tabel 3.

Tabel 3

Respon Kategori Negatif

\begin{tabular}{|c|c|c|c|c|c|c|c|c|}
\hline \multirow{2}{*}{$\mathbf{P}$} & \multicolumn{5}{|c|}{ SKOR KATEGORI RESPON } & \multirow{2}{*}{ TS } & \multirow{2}{*}{$\mathbf{R}$} & \multirow{2}{*}{ K } \\
\hline & SS (5) & S (4) & M (3) & TS (2) & STS (1) & & & \\
\hline 1 & 12 & 8 & 4 & 4 & 2 & 114 & 3.80 & $\mathrm{~S}$ \\
\hline 2 & 14 & 8 & & 8 & & 118 & 3.93 & $\mathrm{~S}$ \\
\hline 3 & 16 & 8 & 2 & 2 & 2 & 124 & 4.13 & $\mathrm{~S}$ \\
\hline 4 & 16 & 8 & 2 & 2 & 2 & 124 & 4.13 & $\mathrm{~S}$ \\
\hline \multicolumn{6}{|c|}{ JUMLAH } & 480 & 16.09 & $\mathbf{S}$ \\
\hline
\end{tabular}

Sumber: Analisis Data Primer, 2014

Berdasarkan hasil perhitungan skala likert pada Tabel 3 maka respon ekowisatawan domestik terhadap masing-masing pernyataan mengenai prostitusi di Bali adalah sebagai berikut:

1. Prostitusi mengganggu ketentraman wisatawan di sebuah destinasi wisata (114/3.80/S).

2. Prostitusi mengurangi kenyamanan wisatawan saat berwisata (118/3.93/S).

3. Prostitusi identik dengan penyakit menular (HIV/AIDS), sehingga membuat wisatawan enggan terlibat dalam kegiatan prostitusi (124/4.13/S). 
4. Prostitusi menurunkan nilai moral masyarakat lokal (124/4.13/S).

Dari 4 pernyataan kategori negatif diperoleh skor rata-rata sebesar 4.02. Jadi persepsi ekowisatawan domestik menunjukan sikap setuju jika prostitusi di Bali dikategorikan sebagai perbuatan yang negatif.

\section{SIMPULAN DAN SARAN}

\subsection{Simpulan}

Persepsi ekowisatawan domestik, menunjukan sikap tidak setuju jika prostitusi di Bali dikategorikan sebagai suatu perbuatan yang positif. Sedangkan jika prostitusi di Bali dikategorikan sebagai suatu perbuatan yang negatif persepsi ekowisatawan domestik menunjukan sikap setuju.

\subsection{Saran}

Banyak cara yang dapat dilakukan untuk mendongkrak kemajuan sektor pariwisata di suatu daerah, dalam hal ini Bali. Salah satunya adalah dengan menciptakan citra yang baik di mata konsumen, tentunya diiringi juga dengan kualitas. Konsumen yang dimaksud adalah ekowisatawan yang saat ini menjadi focus market arah pemasaran pariwisata Bali.

Mengingat kembali apa yang dikatakan Wijayasa (2006), bahwa Bali yang menggunakan budaya sebagai trademark pariwisata, tentu tidak mau "terjebak" dengan fenomena seks (prostitusi) dalam pariwisata. Tentunya jika Bali mampu mempertahankan citra yang ada pada trademark tersebut, tentunya akan mampu 'mencuri' pasar wisatawan yang ada (Negara, 2008). Jika Bali 'mengakui' praktek prostitusi sebagai suatu 'produk' pariwisata, tentunya membuat ketimpangan dengan trademark pariwisata Bali itu sendiri. Prostitusi tentunya jelas bukanlah sesuatu yang sesuai dengan budaya Bali.

Maka dari itu, diharapkan bagi pemerintah terkait, kiranya dapat menindak secara tegas segala macam bentuk prostitusi yang ada di Bali. Terakhir, diperlukan juga penelitian lebih lanjut dari akademisi maupun praktisi sektor pariwisata mengenai sejauh mana prostitusi dibutuhkan di Bali. Tentunya dilihat dari perspektif berbagai elemen, bisa dari pemerintah, masyarakat lokal, ataupun masyarakat pendatang.
Daftar Pustaka:

Arida, Sukma. 2009. Meretas Jalan Ekowisata Bali. Denpasar: Udayana University Press

Gunawan, Imam. 2013. Metode Penelitian Kualitatif: Teori dan Praktik. Jakarta: Bumi Aksara.

Kusherdyana, 2013. Pemahaman Lintas Budaya dalam Konteks Pariwisata dan Hospitalitas. Bandung: Alfabeta.

Martiningsih, Eka. 2007. "Persepsi dan Respon Wanita terhadap Perkembangan Pelacuran di Kota Denpasar". Jurnal Studi Jender Srikandi, vol.6, no.1. 59-68.

Mustari, Muhammad. 2012. Pengantar Metode Penelitian. Yogyakarta. LaksBang PRESSindo.

Pauwah, Yusran. 2013. "Persepsi dan Preferensi Pengunjung terhadap Kawasan Wisata Pantai Malalayang". Jurnal Sabua Universitas Sam Ratulangi, vol.5, no. 1. 16-27.

Pitana dan Gayatri. 2005. Sosiologi Pariwisata. Yogyakarta: Andi.

Ruki, Made. 2010. "Pariwisata Spiritual di Ashram Gandhi Puri Sevagram Klungkung Bali”. Analisis Pariwisata, vol.10, no.1. 41-55

Silalahi, Ulber. 2012. Metode Penelitian Sosial. Bandung: Refika Aditama.

Wijayasa, Wayan. 2006. "Seks dalam Pariwisata: Kajian Awal Faktor-faktor yang Berpengaruh terhadap Berkembangnya Seks dalam Pariwisata". Analisis Pariwisata, vol.7, no.2. 19-29.

Winaya, Made. 2006. "Pelacuran Laki-laki dalam Industri Pariwisata Bali (Studi Kasus Gigolo di Kawasan Wisata Kuta". Analisis Pariwisata, vol.7, no.2. 1-11.

Winia, Nyoman. 2012. "Pariwisata dan Pelacuran di Kawasan Wisata Sanur". Jurnal Perhotelan dan Pariwisata, vol.2, no.1. 37-50.

(16 September 2012) "Wisata seks di Thailand, sumbangan besar devisa Negara, dengan alamat website m.beritasatu.com/wisata-thailand/71867wisata-seks-di-thailand-sumbangan-besar-devisanegara.html (diakses tanggal 13 Maret 2015) 